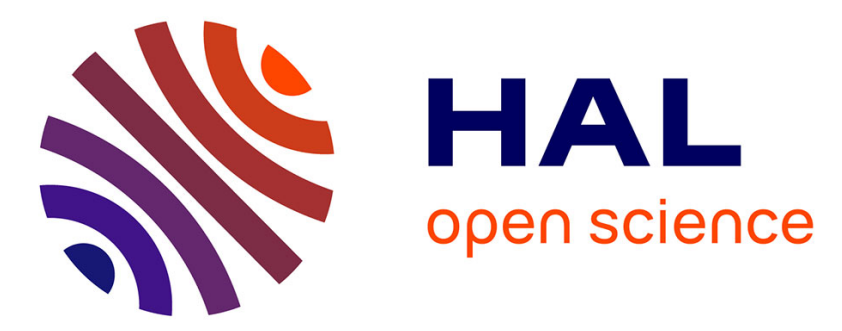

\title{
Valorisation of sediments in self-consolidating concrete: Mix-design and microstructure
}

\author{
Emmanuel Rozière, Mazen Samara, Ahmed Loukili, Denis Damidot
}

\section{To cite this version:}

Emmanuel Rozière, Mazen Samara, Ahmed Loukili, Denis Damidot. Valorisation of sediments in selfconsolidating concrete: Mix-design and microstructure. Construction and Building Materials, 2015, 81, pp.1-10. 10.1016/j.conbuildmat.2015.01.080 . hal-03185655

\section{HAL Id: hal-03185655 \\ https://hal.science/hal-03185655}

Submitted on 8 Jun 2021

HAL is a multi-disciplinary open access archive for the deposit and dissemination of scientific research documents, whether they are published or not. The documents may come from teaching and research institutions in France or abroad, or from public or private research centers.
L'archive ouverte pluridisciplinaire HAL, est destinée au dépôt et à la diffusion de documents scientifiques de niveau recherche, publiés ou non, émanant des établissements d'enseignement et de recherche français ou étrangers, des laboratoires publics ou privés. 


\title{
Valorisation of sediments in self-consolidating concrete: Mix-design and microstructure
}

\author{
E. Rozière ${ }^{a}$, M. Samara ${ }^{\text {b }}$, A. Loukili ${ }^{a, *}$, D. Damidot ${ }^{c}$ \\ a LUNAM Université, Institut de Recherche en Génie Civil et Mécanique (GeM UMR CNRS 6183), Centrale Nantes, 1 rue de la Noe, BP 92101, F-44321 CEDEX 3 Nantes, France \\ ${ }^{\mathrm{b}}$ Laboratoire de Mécanique de Lille (LML) UMR CNRS 8107, and Ecole Centrale de Lille, CS20048, F-59651 Villeneuve d'Ascq Cedex, France \\ ${ }^{\mathrm{c}}$ Université Lille Nord de France, EM Douai, LGCgE-MPE-GCE, Douai, France
}

\section{Introduction}

Over the next 10 years 33.5 million $\mathrm{m}^{3}$ of river sediments are to be dredged in France, where 2.1 million $\mathrm{m}^{3}$ is to be cured in the Nord-Pas-de-Calais region [1]. A part of these sediments is so highly polluted that its management has become an environmental and economical concern for a large number of countries [2]. Contamination is mainly due to organic (PAHs, PCBs, TBT and dioxins) and inorganic (heavy metals: Lead, Chromium, Zinc, Copper) pollutants. Since international and European laws have become more stringent, various alternatives to traditional disposal of the dredged material have been investigated like treatment processes. They allow a reduction in toxicity and volume of dredged material, but in comparison with open-water and upland disposal, their cost

\footnotetext{
* Corresponding author.

E-mail address: ahmed.loukili@ec-nantes.fr (A. Loukili).
}

is not yet competitive enough [3]. This requires innovative ecological valorisation paths for the processed material. Moreover, its beneficial use offers a practical contribution to maximise the conservation of natural raw materials.

Preliminary research had established the feasibility of the fullscale practical use of treated sediments as a partial sand and clay substitute in brick manufacture [4,5]. It has also demonstrated that treated sediment could be introduced with various proportions into the production of mortars [6]. The valorisation in concrete offers a given liberty with respect to granular size distribution and to the choice of quantities and types of materials to substitute (binder or aggregates). Moreover, it would address a current environmental and economical issue related to the pollution generated by cement industry, a major emitter of $\mathrm{CO}_{2}$, and the depletion of natural aggregates. The construction industry in France consumes 400 million tonnes of aggregates per year where $40 \%$ are used for concrete structures. 
Table 1

Total concentrations of heavy metals in raw river sediment in $\mathrm{mg} / \mathrm{kg}$ on dry material.

\begin{tabular}{llllll}
\hline Element & $\begin{array}{l}\text { Cadmium } \\
(\mathrm{Cd})\end{array}$ & $\begin{array}{l}\text { Chromium } \\
(\mathrm{Cr})\end{array}$ & $\begin{array}{l}\text { Copper } \\
(\mathrm{Cu})\end{array}$ & $\begin{array}{l}\text { Lead } \\
(\mathrm{Pb})\end{array}$ & $\begin{array}{l}\text { Zinc } \\
(\mathrm{Zn})\end{array}$ \\
\hline $\begin{array}{l}\text { Raw sediment } \\
\text { Limit values in } \\
\text { soil }\end{array}$ & 12.8 & 413 & 150.7 & $\begin{array}{l}1373 \\
100\end{array}$ & $\begin{array}{l}5032 \\
300\end{array}$ \\
\hline
\end{tabular}

This study was part of an overall project named SEDIBET that aimed to valorise treated sediments in self-consolidating concrete (SCC). This type of concrete represents a major evolution in the construction industry due to the elimination of mechanical compaction. SCC is able to flow under its own weight, completely filling formwork and achieving full compaction, even in the presence of congested reinforcement. SCC mixtures are usually designed with higher volumes of paste (volumes of cement, water, mineral and chemical admixtures) than vibrated concrete mixtures. The design of SCC requires high proportions of fine particles, which generally consist of mineral admixtures such as limestone filler or fly ash. To be used as partial or complete substitution of mineral admixtures, treated sediments should not affect the performances of concrete. They must have a neutral or beneficial effect on workability and properties of early-age concrete, equal or enhanced mechanical properties of hardened concrete, and ensure good durability of reinforced concrete.

Mineral admixtures are often expected to improve the hydration of Portland cement through physical and chemical effects. The finer particles, such as silica fume and limestone microfiller, allow a reduction of the initial porosity of cement paste [7,8]. Mineral admixtures such as fillers often enhance the hydration of cement [9-11]. This increase of hydration degree is often referred to as nucleation effect. The nucleation effect can be generalised as an effect of the specific surface area/cement ratio on hydration [12]. Mineral admixtures may show chemical reactivity. Pozzolanic activity is due to reactions between portlandite and silicate from admixtures such as fly ash and silica fume [12-16].

The present paper first reports an analysis of the particle size distribution. Physical and chemical properties of treated sediments have first been assessed. It gave useful information to investigate their possible use and impact in concrete mix-design. Then a preliminary study on mortars showed their activity with cement and the effects on workability. Finally SCC enabled us to compare the performances of a reference limestone filler SCC and a TS SCC. It included rheological measurements on cement pastes and comprehensive analysis of the microstructure of SCC in order to understand the behaviour of TS in concrete.

\section{Properties of treated sediments}

Raw sediments were collected from Dampremy-Charleroi region (Belgium). The industrial history of this area is marked by several polluting activities like coal mining, iron and steel industry, chemicals and electrical engineering. This explains the significant levels of heavy metals which largely exceed the admissible values (Table 1).

Hence, raw sediments were subjected to a preliminary treatment using the Novosol process which consists of two major phases: phosphatation and calcination. This process was developed and patented by Solvay Company. During the phosphatation phase, raw sediments are mixed with phosphoric acid $\mathrm{H}_{3} \mathrm{PO}_{4}(2-3.5 \%)$ in a tubular reactor. The addition of phosphoric acid allows, in the presence of calcite, the formation of calcium phosphates minerals known for their low solubility and their ability to fix heavy metals [17]. The calcination phase consists of calcining the phosphated sediments at more than $650{ }^{\circ} \mathrm{C}$ in a rotary kiln, in order to break down the organic molecules such as polycyclic aromatic hydrocarbons, dioxins and pesticides. It increases the toughness of the product, reduces the volumes of processed materials and allows a better stabilization of metal phosphates. The treatment of one tonne of raw sediments with a water content of $50 \%$ costs $75 €$. A detailed description of this process is given in [17-19].

Treated sediment (TS) is an odourless heterogeneous granular material of a particle density $\approx 2.8 \mathrm{~g} / \mathrm{cm}^{3}$ (comparable to that of quartz 2.6-2.7 $\mathrm{g} \mathrm{cm}^{-3}$ ) and a specific surface area BET of $\approx 4 \mathrm{~m}^{2} / \mathrm{g}$. The particles of treated sediment are generally angular to round in shape. They are composed mainly of agglomerates of fine sintered leading to poorly cohesive particles (friable and hand crushable). This gives them a high intragranular porosity and hence the ability to absorb a lot of water. Fig. 1 shows that particles have high specific surface, which is likely to result in higher water demand. The particle size distribution is not an intrinsic characteristic of TS. It depends on the way it was handled during the treatment process (mixing during the maturation of phosphated sediment and possible grinding before calcination).

The mineralogical composition of TS depends on the particle size. Optical microscopy of treated sediments done on thin sections confirmed the presence of mineral crystalline phases randomly distributed in the particles (Fig. 2). Some big crystals $(>50 \mu \mathrm{m})$ of quartz, hematite, albite and orthoclase were easily identified. These big crystals were often pasted together with a matrix containing smaller crystals more difficult to identify by optical microscopy. The high internal porosity results from these polysized and poly-mineral grains. The X-ray diffraction (XRD) confirmed optical microscopy observations. It showed that TS is composed mainly of quartz, which gives it the possibility to fulfil

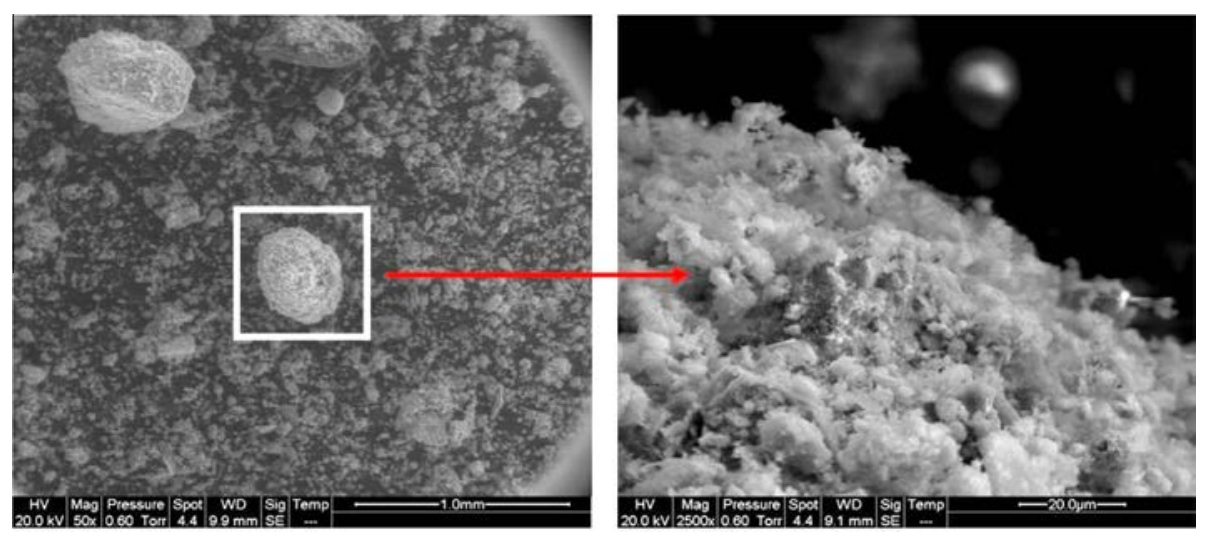

Fig. 1. SEM photomicrograph of a typical particle of treated river sediments [5]. 

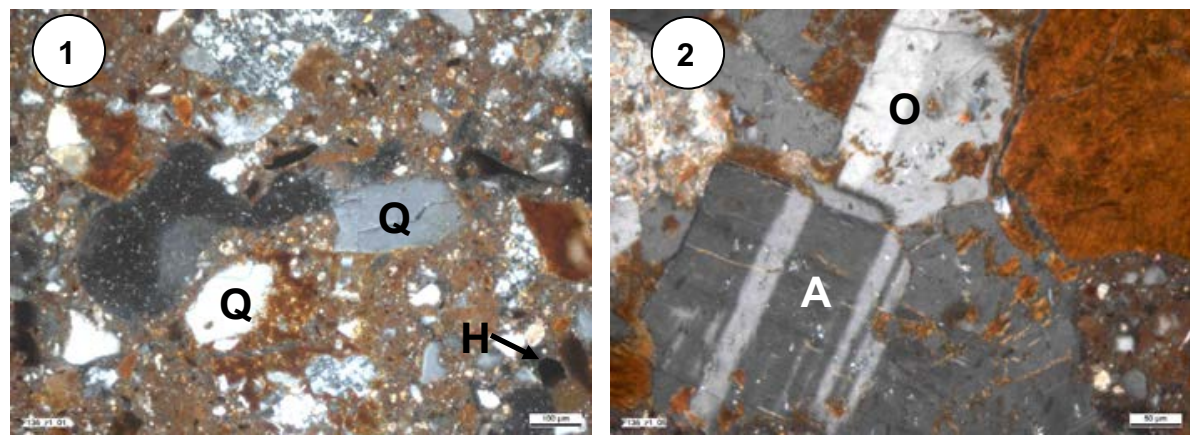

Fig. 2. Polarizing optical images (1: $100 \times ; 2: 200 \times$ ) on thin section of treated sediments (Q: quartz; H: hematite; A: albite; O: orthoclase).

the same role as the quartz sand. It also revealed a marked presence of illite, hematite, plagioclase feldspar (albite), alkali feldspar (orthoclase) and traces of calcite. These minerals are characteristic of treated river sediments [5].

Moreover Scanning Electron Microscopy (SEM) was performed on flat-polished specimens in order to characterise the matrix between the large crystals. Backscattered electron micrographs were made to assess the mineral phase distribution and a semiquantitative study on elemental chemical distribution was carried out by Energy Dispersive X-ray Spectroscopy (EDS). All specimens were epoxy-impregnated and flat-polished according to a standard process [20]. To understand the behaviour of treated sediment in cement paste and in order to analyse concrete microstructures, specific elements that could be used as tracers of sediment were searched. Clay particles and feldspars could be evidenced in areas with high $\mathrm{Al}$ and Si contents, the presence of alkali ( $\mathrm{Na}$ and $\mathrm{K}$ ) and low Ca content (Fig. 3). This specific chemical composition allows locating sediment grains in a cement paste which has a high Ca content but low Si, Al and alkali concentrations [21]. Hematite particles could be found in areas with high concentration of iron and oxygen. As these areas do not contain $\mathrm{Ca}$, they can be distinguished from calcium aluminoferrite contained in Portland cement. Quartz and calcite grains could also be identified from their chemical composition. Nevertheless these minerals are frequently found in sands, thus they could not be used for sediment traceability. Sediment particles with size less than $15 \mu \mathrm{m}$ generally contained phosphorus which is another tracer for fine sediment particles in a cement paste. Phosphorus was sometimes associated with calcium due to the formation of apatites during the phosphatation phase of the Novosol ${ }^{\circledR}$ process. The XRD of TS did not allow defining any crystalline phase containing phosphorus, such as apatite. This suggests that these calcium phosphates are weakly crystalline or their content in sediment is too low to be detected. The second hypothesis was confirmed with semi-quantitative analysis carried out with X-ray Fluorescence (XRF). The chemical composition presented in Table 2 indicates that $\mathrm{P}$ content is close to $1 \%$.

\section{Use of sediments as mineral admixture in mortars}

Mineral admixtures (chemically inert or not) are likely to affect physical and mechanical properties of concrete when they are used as cementitious materials. Limestone filler [8], quartz powder [9], fly ash $[14,15]$, silica fume $[7,13]$, and ground granulated blast furnace slag [22] are often used as mineral admixtures as they can be used as partial replacement of Portland cement and they are likely to improve concrete durability. This enhancement increases with greater powder fineness $[10,11]$. Therefore treated sediment, composed mainly of quartz and calcite, could be thought as a partial replacement of cement.

\subsection{Particle size distribution and properties of TS}

Tests were carried out on mortars, which are more representative than cement pastes. The reference mortar was designed according to the European standard EN 196-1. An ordinary Portland cement (OPC) CEM I 52.5 and $0.08 / 2 \mathrm{~mm}$ normalised quartz sand were used. Three mixes (TS-I, TS-II and TS-III) included the same proportion of TS ( $25 \%$ of the binder content, by mass). All mixes included the same proportions of sand, binder (cement + mineral admixture) and water. In TS-I treated sediment was material passing $0.125 \mathrm{~mm}$ sieve, whereas in TS-II it was crushed and in TS-III it was introduced without any modification. Table 3 gives the specific surface area, measured by the BET method, the mean and median diameters of TS-powders. These values were also measured for the OPC. BET values of all TS-powders were higher than OPC, whereas OPC had lower particle sizes. This means that higher BET values of treated sediments were not due to their particle size distribution but it resulted from the shape and intragranular porosity of particles.

Fig. 4 shows the laser granular analysis of TS powders and cement. From their particle size distribution, sieved and crushed TS can be considered as sandy silt, while the unmodified TS would be considered as silty sand. According to the European standard EN 12620 only crushed TS powder can be considered as filler (passing $63 \mu \mathrm{m}$ sieve $\geqslant 70 \%$ ). The sieving process increased the $63 \mu \mathrm{m}$ fraction from $35 \%$ to $63 \%$, so the sieved TS cannot be considered as filler. However TS particles were poorly cohesive and friable, thus the mixing operations may change the initial particle size distribution shown here and transform coarser materials into finer.

\subsection{Effect on fresh state properties}

Table 4 gives the composition, the slump, workability, initial and final setting values of the mortars. The mortar was mixed for $2.5 \mathrm{~min}$ and then cast into $40 \times 40 \times 160 \mathrm{~mm}^{3}$ moulds. Slump values were measured using the mini cone of Abrams ( $h=150 \mathrm{~mm}$, $D=100 \mathrm{~mm}, d=50 \mathrm{~mm}$ ). The workability of the mortars was measured with the mortar maniabilimeter according to French standards NF P 18-452 and NF P 15-437. The test consists in measuring the flow time of fresh mortar subjected to vibrations.

The initial and final setting values of all mixes were comparable, whereas slump was significantly lower for all TS mixes than for the reference one. Thus TS, due to its porous nature, tended to absorb a high proportion of the water added at the mixing stage leading to a significant decrease in slump and to a significant loss in workability with respect to the reference mortar. As a consequence, the higher losses in workability were associated with the higher BET values of the TS. An increase in spread time by $33 \%$ and $40 \%$ was obtained for TS-I and TS-II respectively compared to TS-III. 

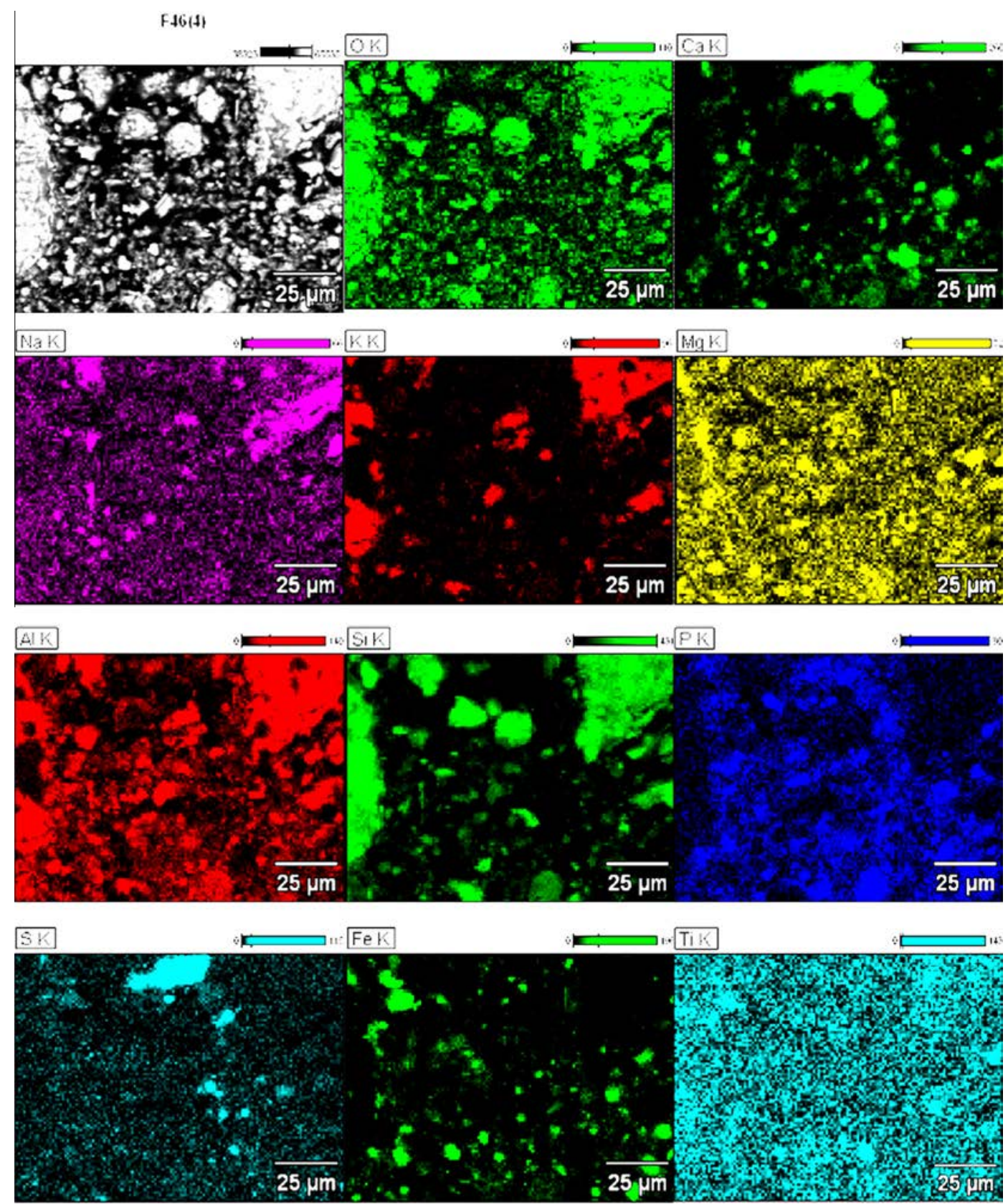

Fig. 3. X-ray maps of treated sediment (Magnification: $1000 \times$ ).

Table 2

Chemical composition of TS (\%).

\begin{tabular}{|c|c|c|c|c|c|c|c|c|c|c|c|c|c|c|}
\hline Element & 0 & $\mathrm{Na}$ & $\mathrm{Mg}$ & $\mathrm{Al}$ & $\mathrm{Si}$ & $\mathrm{P}$ & S & $\mathrm{Cl}$ & K & $\mathrm{Ca}$ & $\mathrm{Ti}$ & Mn & $\mathrm{Fe}$ & $\mathrm{Cu}$ \\
\hline Mass & 48.1 & 1.9 & 1.6 & 7.3 & 24.3 & 1.0 & 0.3 & 0.1 & 2.2 & 5.0 & 0.4 & 0.1 & 7.5 & 0.1 \\
\hline
\end{tabular}

Table 3

Properties of cement and TS powders used for the preparation of mortars.

\begin{tabular}{|c|c|c|c|c|}
\hline & \multicolumn{3}{|c|}{ Treated sediment } & \multirow{2}{*}{$\begin{array}{l}\text { Cement } \\
\text { CEM I } 52.5\end{array}$} \\
\hline & Sieved & Crushed & Unmodified & \\
\hline Median particle size $(\mu \mathrm{m})$ & 48.61 & 28.96 & 122.4 & 16.13 \\
\hline Mean particle size $(\mu \mathrm{m})$ & 56.15 & 41.01 & 218.5 & 19.83 \\
\hline Specific surface area BET $\left(\mathrm{m}^{2} / \mathrm{g}\right)$ & 5.06 & 5.71 & 3.86 & 1.09 \\
\hline
\end{tabular}




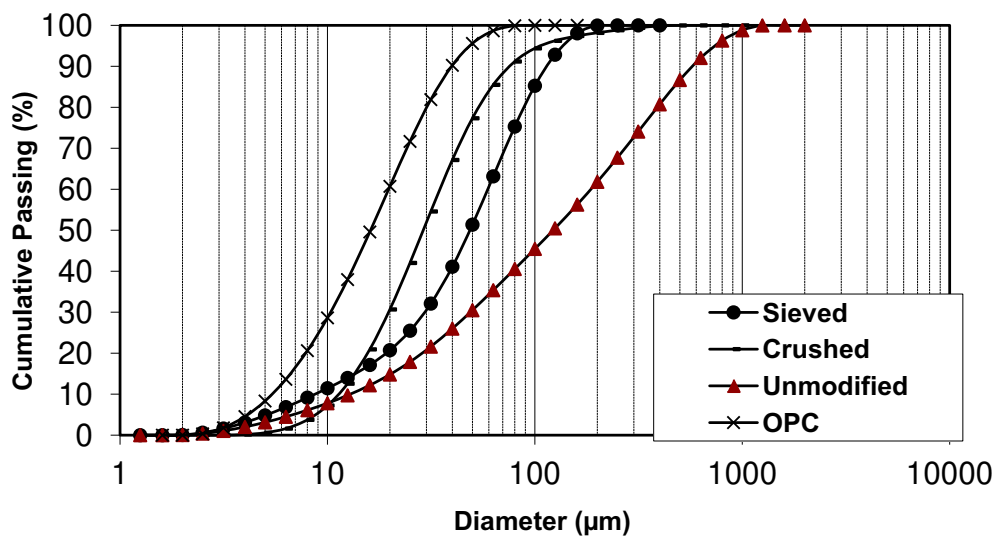

Fig. 4. Particle size distribution of TS and cement used in mortar specimens.

Table 4

Composition of mortars.

\begin{tabular}{lllll}
\hline & REF & TS-I & TS-II & TS-III \\
\hline Normalised sand $(\mathrm{g})$ & 1350 & 1350 & 1350 & 1350 \\
Cement CEM I 52,5 $(\mathrm{g})$ & 450 & 338 & 338 & 338 \\
TS $(\mathrm{g})$ & - & 113 & 113 & 113 \\
Water $(\mathrm{g})$ & 225 & 225 & 225 & 225 \\
Water/binder & 0.50 & 0.50 & 0.50 & 0.50 \\
TS/binder & 0 & 0.25 & 0.25 & 0.25 \\
Slump (cm) & 8.5 & 1.0 & 0.6 & 1.0 \\
Workability (s) & 2.3 & 8.0 & 8.4 & 6.0 \\
Initial/final setting (h) & $3.25 / 6.03$ & $3.48 / 5.95$ & $3.27 / 5.67$ & $2.95 / 5.08$ \\
\hline
\end{tabular}

\subsection{Activity of sediments as mineral admixture}

The relative performance of TS as a cementitious material was assessed through the Bolomey strength relationship (Eqs. (1) and (2)) from compressive strength test results.

$$
F_{0}=K_{B}\left(\frac{C_{0}}{W+V}-0.5\right)
$$

$f_{p}=K_{B}\left(\frac{C+\chi_{B} A}{W+V}-0.5\right)=K_{B}\left(\frac{\left((1-p)+p \chi_{B}\right) C_{0}}{W+V}-0.5\right)$

where $f_{0}$ is the average compressive strength of the reference mor$\operatorname{tar}, f_{p}$ the average compressive strength of sediment-based mortar, $K_{B}$ is the Bolomey coefficient, $C_{0}$ and $C$ are the cement contents in reference and sediment-based mortars respectively $\left(\mathrm{kg} / \mathrm{m}^{3}\right), W$ is the water content in mortar $\left(\mathrm{kg} / \mathrm{m}^{3}\right), V$ is the air content in mortar $\left(\mathrm{m}^{3} / \mathrm{m}^{3}\right), p$ is the replacement ratio and $\chi_{B}$ is the coefficient of activity defined as the part of TS which can be considered equivalent to Portland cement. $\chi_{B}$ can be deduced from relations (1) and (2) as given below:

$i=\frac{f_{p}}{f_{0}}$

$\chi_{B}=1+\frac{i-1}{p}\left(1-0.5 \frac{W+V}{C_{0}}\right)$

where $i$ is the activity index defined as the ratio of the average compressive strength of sediment-based mortar $f_{p}(t)$ to the average compressive strength of the reference mortar $f_{0}(t)$ [23]. According to the French standard NF EN 450 (for $p=0.25$ ), the activity index for fly ash admixtures should be higher than 0.75 and 0.85 at 28 and 90 days, respectively.
Compressive strength was measured after 2, 7, 28 and 90 days of water curing at temperature of $20^{\circ} \mathrm{C}$. The average values in Fig. 5 indicate that compressive strength at 2 and 7 days was lower for all TS mixes relative to the reference mortar. After a longer curing period, the difference in strength was less pronounced for TS-I and TS-II mixes. This was probably due to the participation of water; absorbed by TS at the mixing stage, in the hydration process resulting in a higher amount of hydrates. Moreover it could be also due to the pozzolanic activity of TS, as it has been shown that this material is likely to provide a certain pozzolanic activity [24]. This activity was noticed after few days and it tended to increase with powder fineness. Moreover, it has been shown that finer TS powders exhibited lower porosity values [25] resulting in denser mixes. At 28 and 90 days compressive strength values for TS-I and TS-II mixes were comparable to those of the REF one, whereas TS-III was the mix with the lowest strength values. The influence of admixture fineness on the compressive strength of mortars has already been investigated. It has been shown that the decrease of particle size favours nucleation of the products of cement hydration on mineral particles $[10,11]$.

The activity index and the coefficient of activity of all mixtures are summarised in Table 5 . A correlation between these values and the fineness of TS is also observed, where higher $i$ and $\chi_{B}$ values have been obtained for finer powders (Fig. 6). Thus, if TS is to be used as a suitable cementitious material, it must undergo either sieving or crushing processes.

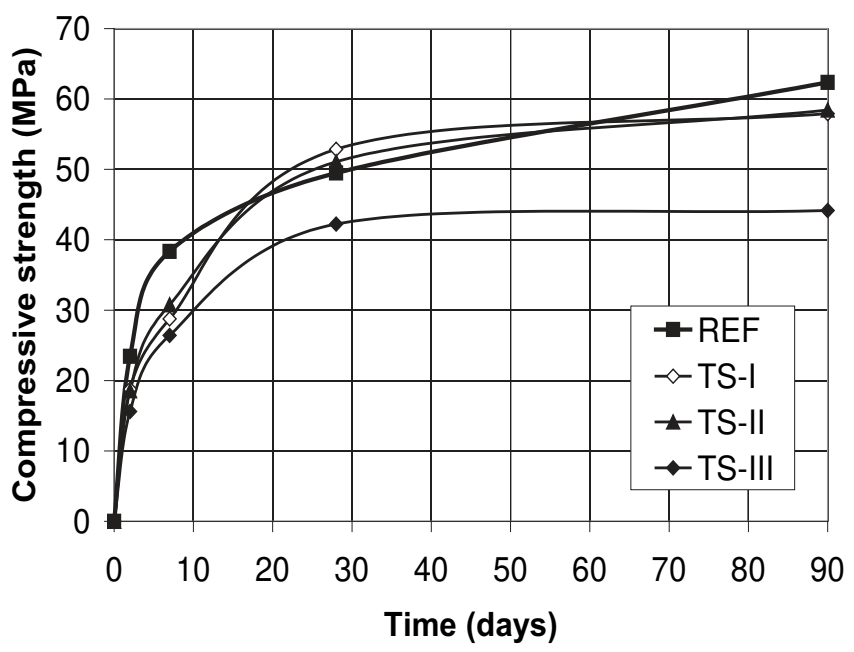

Fig. 5. Compressive strength development of mortar specimens. 
Table 5

Activity index and coefficient of activity of TS in mortars.

\begin{tabular}{llllllll}
\hline \multirow{2}{*}{ Curing time } & \multicolumn{3}{l}{ Activity index } & & & \multicolumn{3}{c}{ Coefficient of activity } \\
\cline { 2 - 3 } & TS-I & TS-II & TS-III & & TS-I & TS-II & TS-III \\
\hline 2 & 0.80 & 0.79 & 0.67 & & 0.40 & 0.37 & 0.00 \\
7 & 0.75 & 0.80 & 0.69 & & 0.25 & 0.41 & 0.07 \\
28 & 1.07 & 1.03 & 0.85 & & 1.20 & 1.10 & 0.56 \\
90 & 0.93 & 0.94 & 0.71 & & 0.79 & 0.81 & 0.12 \\
\hline
\end{tabular}

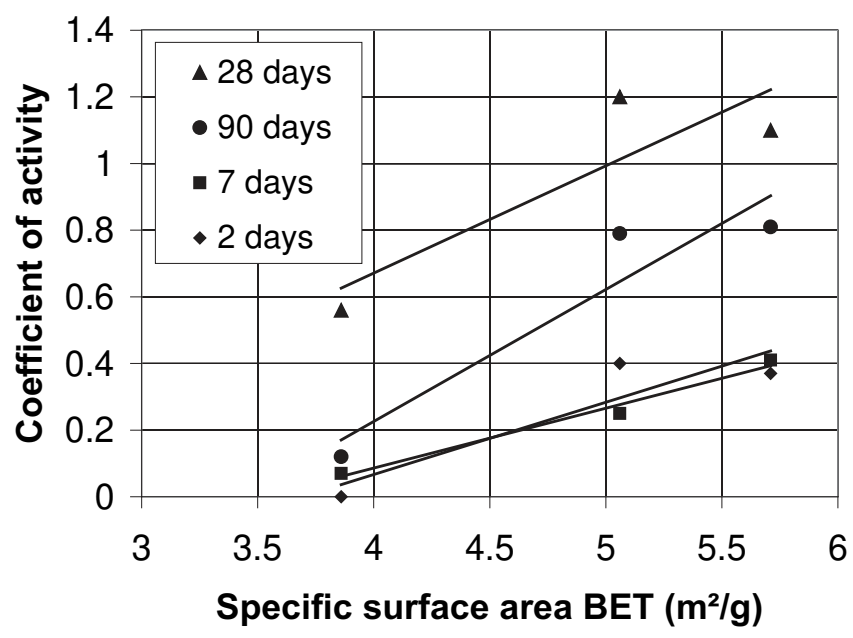

Fig. 6. Correlation between specific surface and coefficient of activity.

\section{Design and properties of self-consolidating concrete mixtures}

A self-consolidating concrete (SCC) mixture incorporating TS was compared with a reference SCC mixture with limestone filler. The SCC specimens were prepared using TS02 with a particle size ranging between 0 and $2 \mathrm{~mm}$ (Table 6 ). The fraction passing $63 \mu \mathrm{m}$ was only $20 \%$, thus, according to the Standard EN 12620 , TS02 cannot be considered as filler. Moreover, the fraction of particle sizes higher than $160 \mu \mathrm{m}$ was around 60\%; therefore TS02 can be used as fine sand substitution. Sieving and crushing could have improved the activity of TS (see Section 3.3) but sieving would have resulted in a significant loss of material and crushing was not necessary as the biggest TS particles were crushed during concrete mixing (see Section 4.4). As a consequence TS02 was directly used to design the SCC mixture.

\subsection{Mix-design methods and fresh state properties}

SCC mixtures were designed using the method recommended by Turcry [26]. A well-graded $0 / 4$ sea sand (S) with a fines content $(<80 \mu \mathrm{m})$ lower than $1 \%$, a $4 / 12$ gravel $(G)$ and an ordinary Portland cement CEM I 52.5 (C) were used for the preparation of concrete specimens. A polycarbolaxate superplasticizer ( $\mathrm{Sp}$ ) was used to

Table 6

Particle size analysis of TS used in TS-SCC mixture (mass \%).

\begin{tabular}{lc}
\hline Particle sizes & TSO2 \\
\hline Coarse sand, $>500 \mu \mathrm{m}$ & 32.7 \\
Medium sand, $250-500 \mu \mathrm{m}$ & 17.0 \\
Fine sand, $63-250 \mu \mathrm{m}$ & 30.9 \\
$<63 \mu \mathrm{m}$ & 19.4 \\
\hline
\end{tabular}

Table 7

Composition of the SCC mix-designs.

\begin{tabular}{lll}
\hline$\left(\mathrm{kg} / \mathrm{m}^{3}\right)$ & LF-SCC (reference) & TS-SCC \\
\hline Gravel & 840 & 796 \\
Sand & 828 & 783 \\
Cement & 323 & 355 \\
Limestone filler & 151 & - \\
Treated sediment & - & 166 \\
W & 185 & 204 \\
Sp & 2.0 & 2.0 \\
W/C & 0.57 & 0.57 \\
W/B & 0.39 & 0.39 \\
Volume of paste $\left(1 / \mathrm{m}^{3}\right)$ & 345 & 380 \\
Slump flow $(\mathrm{cm})$ & 72 & 66 \\
\hline
\end{tabular}

ensure the deflocculation of fine particles. Its content was adjusted to produce slump flow between 650 and $750 \mathrm{~mm}$, typical values for SCC. Two mixes were prepared, namely: LF-SCC and TS-SCC. Their proportions are summarised in Table 7.

We note that in sediment-based mixture limestone filler (LF) used for the preparation of reference concrete was completely replaced by TSO2. The paste volume was increased by $10 \%$ with respect to reference concrete in order to provide a satisfactory SCC mix-design [27]. The increase was dictated by the particle size distribution of TS02 and the results from rheological analysis (see results below). The water-cement ratio $(W / C)$ and the waterbinder ratio $(W / B)$ were kept constant in the two mixes.

Gravel, sand, cement and limestone filler (or TS02) were first introduced and dry mixed for $30 \mathrm{~s}$. Then, water was progressively added. After $30 \mathrm{~s}$, the superplasticizer was poured and the constituents were mixed for $3 \mathrm{~min}$. Concrete specimens were cast into $11 \times 22 \mathrm{~cm}$ cylindrical moulds and were stored in a room at $20^{\circ} \mathrm{C}$ and $95 \%$ of relative humidity $(\mathrm{RH})$.

Workability is a crucial factor that affects the application of SCC, since this type of concrete is required to have high fluidity, deformability, good filling ability, and adequate resistance to segregation. Workability of freshly mixed concrete is quantified by the slump flow test, which measures the flow capacity. Results are included in Table 7. A spread value of $660 \mathrm{~mm}$ was obtained for the TS02-SCC mix design. This value is lower than that of LFSCC $(720 \mathrm{~mm})$, which confirms the previous results obtained for mortar mixes indicating the negative effect of TS on workability.

\subsection{Rheology of pastes}

The rheological properties of cement-based suspensions, such as mortar and concrete, are often described by the Bingham model [28-30]. Two parameters define the flow: yield stress and plastic viscosity [31]. For a given gravel/sand ratio the rheological properties of concrete are mainly influenced by the rheological parameters of cement paste (including mineral admixtures). Therefore, rheological measurements were undertaken only on cement paste. They do not take into account for the contribution of aggregates which shear the cement paste during the mixing process [32]. Two cement pastes have been studied where two mineral admixtures were used: limestone filler (LF) and TS02. The admixture-binder ratio, the water-binder ratio and the superplasticizer-binder ratio were kept constant in both mixes and equal to those of corresponding concretes (Table 7).

The rheological parameters were determined using an AR550 (TA Instruments) rheometer with coaxial geometry. Two tests were undertaken for each composition (Fig. 7). They indicate that the substitution of LF by TS02 resulted in a significant increase in yield stress of the paste. This explains the decrease in the slump (Table 7) since the latter is directly related to yield stress. The increase in 


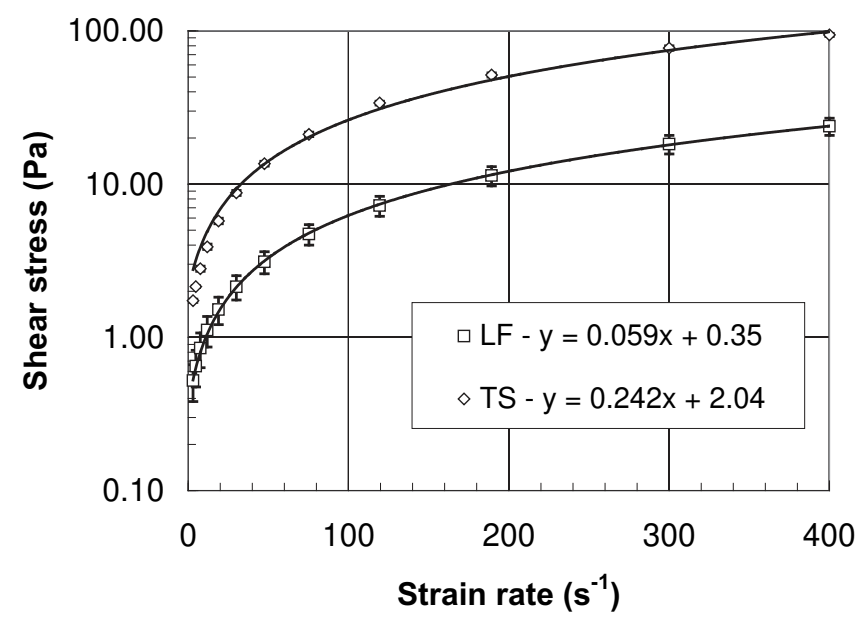

Fig. 7. Rheological behaviour of cement pastes.

viscosity could be due to the absorption of water, as TS particles showed high internal porosity.

\subsection{Mechanical properties}

Compressive strength is the most widely used requirement for hardened concrete. Moreover it is used in standards (NF EN 2061 ) as a general durability indicator. The tests were undertaken on three $11 \times 22 \mathrm{~cm}$ cylindrical samples of each SCC mixture. The average results at 2, 7, 28 and 90 days are given in Fig. 8 .

The compressive strength of TS02-based samples was equal to those of reference concrete. TS-SCC mixture had higher cement content but the water/cement ratio was kept content, and the LF/ cement and TS/cement ratios were equal (Table 7). TS-SCC mixture had higher volume of paste $(+10 \%)$ than LF-SCC mixture. Higher volume of paste generally results in lower compressive strength [27], but this was not observed here, which suggests that the activity of TS was higher than LF. The substitution of LF actually resulted in a dense and homogeneous solid matrix as confirmed by the density measurements (Table 8) and the microstructure analysis of both mixes (see results below). The absolute density of TS02-based concrete samples was equal to that of reference concrete. Thus the porous nature of TS02 was counteracted by the dense solid matrix. Additionally, this might be also explained by the tendency of TS02

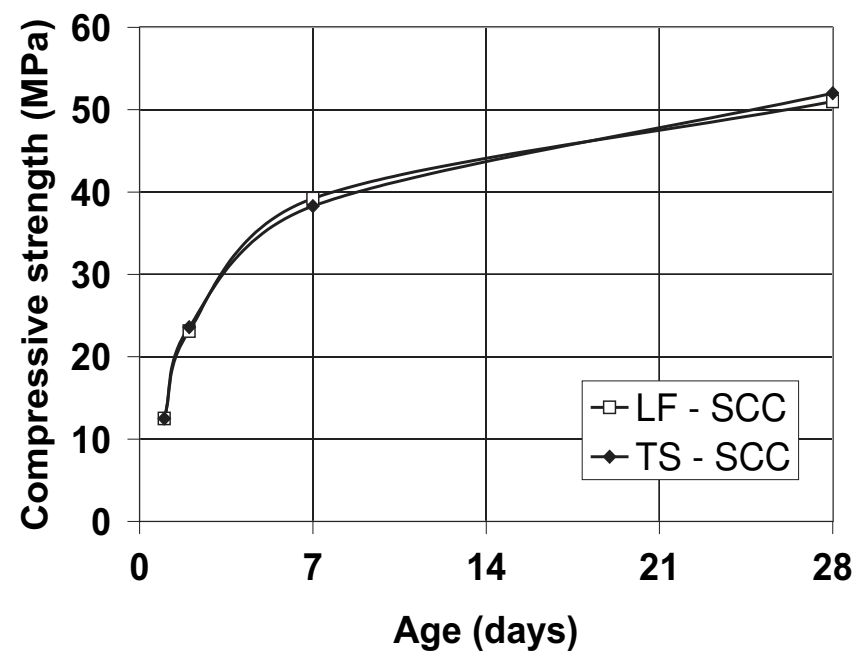

Fig. 8. Compressive strength of SCC mixtures.
Table 8

Mean values of connected porosity and densities of the two mix-designs.

\begin{tabular}{lll}
\hline & LF-SCC & TS02-SCC \\
\hline Apparent density $\left(\mathrm{kg} / \mathrm{m}^{3}\right)$ & 2323 & 2249 \\
Absolute density $\left(\mathrm{kg} / \mathrm{m}^{3}\right)$ & 2600 & 2606
\end{tabular}

to provide nucleation sites for hydrates leading to an enhancement of the hydration process.

\subsection{SEM observations and analyses}

Backscattered electron micrographs of TS-SCC specimens in paste zones are presented in Fig. 9. TS particles $>1 \mathrm{~mm}$ could not be detected. This indicates that large particles have been partially dissociated into smaller ones during mixing. Moreover, the microstructure can be considered as heterogeneous with respect to the distribution of TS particles and minerals (contained in TS) within the cement paste. For example the distribution of apatite, obtained by X-ray maps of $\mathrm{P}$ and $\mathrm{Ca}$, is heterogeneous (Fig. 10). Hematite, albite and orthoclase contained in TS did not react with the cement paste. We can also notice that the cement paste is quite dense. This is mainly due to the high percentage of cement hydration despite higher cement content as only a few anhydrous cement grains are observed and also to the good distribution of small sediment particles within the cement paste.

The X-ray maps actually revealed that phosphorus (contained in small TS particles) is homogeneously distributed within the hydrates of the cement paste (Fig. 10). This is also true for $\mathrm{Al}, \mathrm{Si}$ and $\mathrm{Mg}$ which confirms that fine particles, i.e. clay particles and feldspar, are well-dispersed within the cement paste. A good affinity of $\mathrm{C}-\mathrm{S}-\mathrm{H}$ to small TS particles could be assumed in order to explain the high percentage of reaction observed. $\mathrm{C}-\mathrm{S}-\mathrm{H}$ would actually nucleate on these fine particles containing phosphorus as they nucleate on calcite of limestone filler.

\subsection{Micromechanics analysis}

The observations presented in Section 4.4 showed that fine particles were well dispersed and associated with high degree of reaction, thus they could have locally enhanced the mechanical properties of the cement paste of TS-SCC specimens by the nucleation of $\mathrm{CSH}$. In order to confirm this assumption, nanoindentation measurements have been performed on flat-polished LF-SCC and TS-SCC specimens without epoxy-impregnation.

The tests have been performed at MicroLab in TU Delft in collaboration with Prof. E. Schlangen. The procedure consists in increasing multi-cyclic loading. The studied zones had been previously defined using both electron and optical microscopy. The zones are actually chosen using an optical microscope in the nano-indenter but the localisation is difficult. Therefore the localisation of the indents is verified using electron microscopy. In order to obtain more reliable results, series of five indentations have been performed moving the indenter from an anhydrous particle (generally $\mathrm{C}_{2} \mathrm{~S}$ ) towards hydrated cement paste. The measurements were also made to calibrate the apparatus using values given in Velez et al. as a reference [33]. The average values from more than 20 measurements show that where fine TS particles (containing phosphorus) could be found the elastic modulus of the cement paste was increased by $20 \%$. The average values of the elastic modulus of hydrated cement paste that mostly contained $\mathrm{C}-\mathrm{S}-\mathrm{H}$ were 23.0 and $27.5 \mathrm{GPa}$ for $\mathrm{LF}-\mathrm{SCC}$ and TS-SCC respectively (see Fig. 11).

This is consistent with the reduction of the macroporosity of the cement paste of TS-SCC specimens. However the improvement of mechanical properties at the paste scale does not result in 

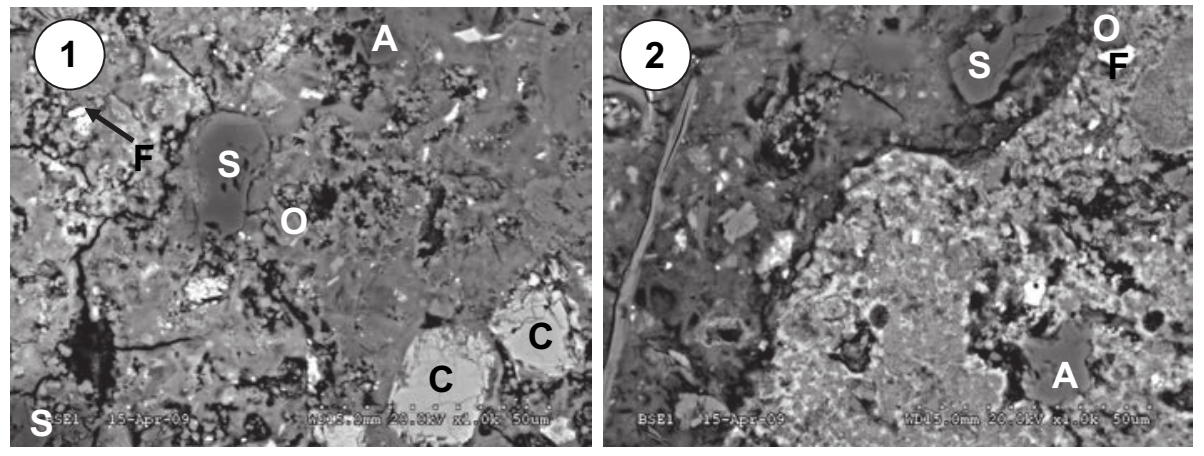

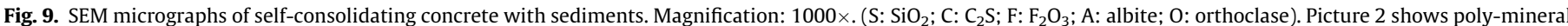
sediment grain in right-hand side of the micrograph (light grey level).
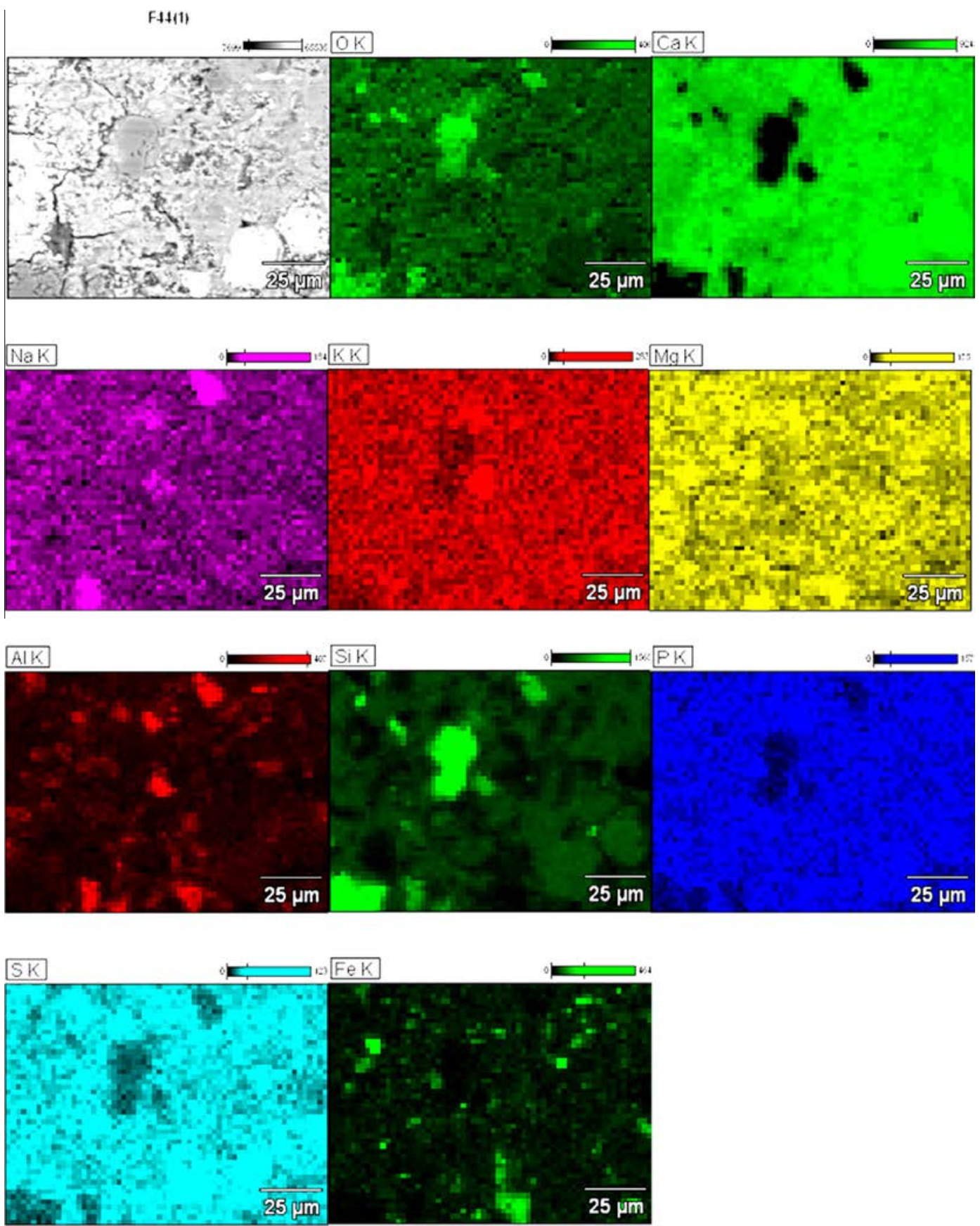

Fig. 10. X-ray maps of self-consolidating concrete with sediments. Magnification: $1000 \times$. 

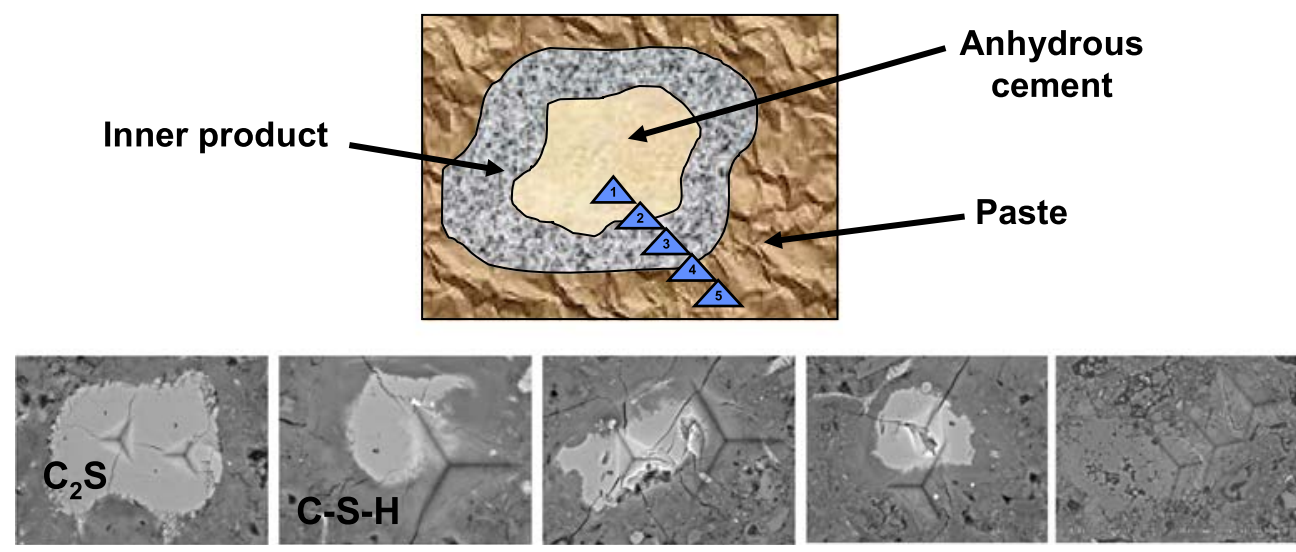

Fig. 11. Localisation of indents (after measurements) from anhydrous cement particles towards inner C-S-H and cement paste.

enhanced global properties because TS are heterogeneities at the macroscopic scale. The biggest TS particles actually consisted of poly-mineral grains with high internal porosity (Section 2), thus they lead to a decrease in macroscopic mechanical properties in spite of enhanced properties at microscopic scale.

\section{Conclusion}

This study investigated the potential use of treated sediments in self-consolidating concrete. TS are produced from raw sediments through an industrial treatment using the Novosol ${ }^{\circledR}$ process which consists of two major phases: phosphatation and calcination. The main findings are the following.

- TS are a 0/2 mm powder composed mainly of poly-mineral grains and agglomerates of fine sintered poorly cohesive particles. This gives it a high intragranular porosity and the ability to absorb a lot of water.

- The relative performance of treated sediments as regards Portland cement was predicted by applying the concept of coefficient of activity based on compressive strength values and on Bolomey relationship. Compression tests on mortars have shown a certain activity of TS with cement and hence treated sediments could be used as cementitious material. Nevertheless, the activity of this material is closely related to its fineness, where higher coefficients of activity were obtained for finer TSpowders.

- TS were incorporated in SCC as a replacement of limestone filler and aggregates. The volume of paste in TS SCC mixture was increased by $10 \%$ with respect to reference concrete. This increase was dictated by the particle size distribution of TS and by the required slump flow. The average compressive strength values of TS-based concrete specimens are comparable to those of reference concrete.

- The use of TS has a negative effect on fresh-state properties of SCC. The rheological measurements on pastes have shown that yield stress and viscosity increased with replacement of LF with TS, while a loss in workability has been observed. This could be explained by the porous nature of TS which tends to absorb and hold a proportion of the water added at the mixing stage resulting in a significant decrease in slump flow.

- The microstructure analysis has shown that the use of TS resulted in a dense solid matrix and a homogeneous material. The particle size distribution of TS is not an intrinsic property as the biggest particles are likely to be crushed during mixing. The fine particles of TS are well dispersed and they favour the hydration process and the nucleation of hydrated products.
- The TS and the TS concrete mixtures have been studied according to test procedures and a methodology that could be applied to other materials.

From the experimental results of this study, TS can be used as a cementitious material in concrete. Designing TS-SCC mixture requires higher volume of paste thus higher cement content to reach equivalent workability but TS-based mixtures enables the valorisation of significant amount of sediments. The initial mean particle size of TS was relatively high but the microstructure analyses showed that the biggest particles were crushed during concrete mixing. TS-SCC had a dense cement paste and equivalent compressive strength. The durability and leaching of TS-based concrete needs further investigation.

\section{Acknowledgements}

The authors wish to acknowledge the financial support from national network ANR SEDIBET. Assistance provided by E. Schlangen, G. Louis and C. Gardes for microstructural characterization and nanoindentation is gratefully acknowledged.

\section{References}

[1] Agence de l'eau Artois Picardie, Les qualités des sédiments des cours d'eau: etude 1991-1996, in French; 1997.

[2] Marot F, Caractérisation et traitement de sédiments de dragage contenant des polluants métalliques. BRGM, editors; 1998.

[3] Mannino I, Soriani S, Zanetto G, Management of port dredged material: an environmental-political issue, littoral 2002; the changing coast. EUROCOAST/ EUCC, Porto - Portugal, Ed. EUROCOAST - Portugal.

[4] Lafhaj Z, Samara M, Agostini F, Boucard L, Skoczylas F, Depelsenaire G. Polluted river sediments from the North region of France: treatment with the Novosol ${ }^{\circledR}$ process and valorization in clay bricks. Constr Build Mater 2008;22:755-62.

[5] Samara M, Lafhaj Z, Chapiseau C. Valorization of stabilized river sediments in fired clay bricks: factory scale experiment. J Hazard Mater 2009;163:701-10.

[6] Agostini F, Inertage et valorisation des sédiments de dragage marin [Ph.D. thesis]. France: Ecole Centrale de Lille; 2005.

[7] Buil M, Paillère AM, Roussel B. High strength mortar containing condensed silica fume. Cem Concr Res 1984;14(5):693-704.

[8] Soroka I, Stern N. Calcareous fillers and the compressive strength of Portland cement. Cem Concr Res 1976;6:367-76.

[9] Jiang SP, Mutin JC, Nonat A, Effect of fillers (fine particles) on the kinetics of cement hydration, Proc. 3rd Beijing Int. Symp. on Cement and Concrete III, Beijing: China Building Materials Academy; 1993, pp. 132-137.

[10] Lawrence Ph, Cyr M, Ringot E. Mineral admixtures in mortars, effect of inert materials on short-term hydration. Cem Concr Res 2003;33:1939-47.

[11] Cyr M, Lawrence Ph, Ringot E. Efficiency of mineral admixtures in mortars: quantification of the physical and chemical effects of fine admixtures in relation with compressive strength. Cem Concr Res 2006;36:264-77.

[12] Idir R, Cyr M, Tagnit-Hamou A. Pozzolanic properties of fine and coarse colormixed glass cullet. Cem Concr Compos 2011;33:19-29.

[13] Cheng-Yi H, Feldman RF. Hydration reactions in Portland cement-silica fume blends. Cem Concr Res 1985;15:585-92. 
[14] Maltais Y, Marchand J. Influence of curing temperature on cement hydration and mechanical strength development of fly ash mortars. Cem Concr Res 1997;27(7):1009-20.

[15] Younsi A, Turcry P, Rozière E, Aït-Mokhtar A, Loukili A. Performance-based design and carbonation of concrete with high fly ash content. Cem Concr Compos 2011;33(10):993-1000.

[16] Aubert JE, Husson B, Sarramone N. Utilization of municipal solid waste incineration (MSWI) fly ash in blended cement, Part 1: Processing and characterization of MSWI fly ash. J Hazard Mater 2006;B136:624-31.

[17] Kahalé N, Novosol ${ }^{\circledR}$ process: sludge stabilisation and beneficial reuse. Proceeding of the 2nd international conference on remediation of contaminated sediments. Venice, Italy: Batelle Press; 2003.

[18] Publication EP1341728 (19/04/2002). Patent correspondent: FR2815338 (17/ 10/2000). Procédé d'inertage de boues. SOLVAY.

[19] Aubert JE, Valorisation d'une cendre d'incinérateur d'ordures ménagères, traitée par le procédé REVASOL ${ }^{\circledR}$, dans le béton hydraulique [Ph.D. thesis]. Toulouse, France: Université Paul Sabatier de; 2002.

[20] Kjellsen KO, Monsoy A, Isachsen K, Detwiler RJ. Preparation of flat-polished specimens for SEM-backscattered electron imaging and X-Ray microanalysis importance of epoxy impregnation. Cem Concr Res 2003;33:611-6.

[21] Famy C, Scrivener KL, Crumbie AK. What causes differences of C-S-H gel grey levels in backscattered electron images? Cem Concr Res 2002;32:1465-71.

[22] Khokhar MIA, Rozière E, Turcry P, Grondin F, Loukili A. Mix design of concrete with high content of mineral additions: optimisation to improve early age strength. Cem Concr Compos 2010;32(5):377-85.

[23] Lawrence Ph, Ringot E, « Prise en compte des additions minérales dans le calcul des résistances de mortiers », Revue Française de Génie Civil, vol. 4 - n4/2000, pp. 525-541.
[24] Scordia PY, Lafhaj Z, Skoczylas F, Mongeois F. Caractérisation et valorisation en technique routière de sediments fluviaux pollués et traits. Rev Eur Génie Civ 2008;12(9-10):1087-104.

[25] Samara M, Valorisation des sediments fluviaux pollués après inertage dans la brique cuite [Ph.D. thesis]. France: Ecole Centrale de Lille; 2007.

[26] Turcry Ph, Retrait et fissuration des bétons autoplaçants Influence de la formulation [Ph.D. thesis]. France: Ecole Centrale de Nantes; 2004.

[27] Rozière E, Granger S, Turcry P, Loukili A. Influence of paste volume on shrinkage cracking and fracture properties of self-compacting concrete. Cem Concr Compos 2007;29(8):626-36.

[28] Banfill PFG. Rheology of fresh cement and concrete. London: E\&FN Spon; 1991.

[29] Beaupré D, Rheology of High Performance Shotcrete [Ph.D. thesis]. Canada: University of British Columbia; 1994.

[30] De Larrard F, Sedran T, Hu C, Sitzkar JC, Joly M, Derkx F. Evolution of the workability of superplasticized concretes: assessment with BTRHEOM rheometer. In: Bartos PJM, Marrs DL, Cleland DJ, editors. Proceedings of the international RILEM conference on production methods and workability of concrete. Paisley: RILEM; 1996. p. 377-88.

[31] Ferraris CF, de Larrard F, Martys N. In: Skalny J, editor. Fresh concrete rheology recent developments, material science of concrete, vol. 6. OH, USA: ACers: 2001.

[32] Bartos P. Fresh concrete: properties and tests. New York: Elsevier; 1992.

[33] Velez K, Maximilien S, Damidot D, Fantozzi G, Sorrentino F. Determination by nanoindentation of elastic modulus and hardness of pure constituents of Portland cement clinker. Cem Concr Res 2001;31:555-61. 